\title{
Molecular characterization of Moenkhausia (Pisces: Characiformes) populations with different lateral line developmental levels
}

\author{
THAÍS F.M. MOTA ${ }^{1}$, THOMAZ M.C. FABRIN ${ }^{2}$, GABRIEL C. DEPRÁ ${ }^{2}$, LUCIANO S. GASQUES $^{3}$, ALESSANDRA \\ V. DE OLIVEIRA ${ }^{4,5}$, CARLA S. PAVANELLI ${ }^{1,2,5}$, SÔNIA M.A.P. PRIOLI ${ }^{1,4,5}$ and ALBERTO J. PRIOLI ${ }^{1,5}$ \\ ${ }^{1}$ Programa de Pós-Graduação em Biologia Comparada, Universidade Estadual de \\ Maringá, Av. Colombo, 5790, 87020-900 Maringá, PR, Brazil \\ ${ }^{2}$ Programa de Pós-Graduação em Ecologia de Ambientes Aquáticos Continentais, Universidade \\ Estadual de Maringá, Av. Colombo, 5790, 87020-900 Maringá, PR, Brazil \\ ${ }^{3}$ Departamento de Ciências Biológicas, Universidade Paranaense, Praça Mascarenhas \\ de Moraes, 4282, Zona III, 87502-210 Umuarama, PR, Brazil \\ ${ }^{4}$ Departamento de Biotecnologia, Genética e Biologia Celular, Universidade Estadual \\ de Maringá, Av. Colombo, 5790, 87020-900 Maringá, PR, Brazil \\ ${ }^{5}$ Núcleo de Pesquisas em Limnologia, Ictiologia e Aquicultura, Universidade Estadual \\ de Maringá, Av. Colombo, 5790, 87020-900, Maringá, PR, Brazil
}

Manuscript received on July 4, 2017; accepted for publication on January 12, 2018

\begin{abstract}
The genera Hemigrammus and Moenkhausia have been traditionally diagnosed mainly by the former having lateral line completely pored whereas the latter having a lateral line with a few pored scales. Those features have been used to diagnose species of both genera in the upper Paraná River floodplain. Specimens with the diagnostic features of Moenkhausia bonita, collected in the upper Paraná River floodplain, exhibited different developmental levels of the lateral line, making it difficult to distinguish them from specimens of Hemigrammus sp. We analyzed the gene encoding cytochrome C oxidase I (COI) and intron 1 of the nuclear gene $\mathrm{S} 7$ to investigate the genetic similarities between the called Hemigrammus marginatus and $M$. bonita and to confirm their identities. Molecular sequences of other Moenkhausia species were analyzed for genus delimitation tests. The results reveal genetic similarities of $M$. bonita specimens with different developmental levels of the lateral line, and also distinguish between M. bonita and Hemigrammus sp. Species delimitation tests revealed that specimens from the upper Paraná River floodplain were M. bonita and were distinct from other Moenkhausia species. The developmental level of the lateral line is not a consistent characteristic that distinguishes between Moenkhausia and Hemigrammus species.
\end{abstract}

Key words: Cytochrome $\mathrm{C}$ oxidase, delimitation of species, DNA barcode, Hemigrammus, Intron 1 of the nuclear gene S7, Paraná River.

Correspondence to: Thaís Fernandes Mendonça Mota

E-mail: tfmm_0412@hotmail.com 


\section{INTRODUCTION}

Moenkhausia Eigenmann, 1903 and Hemigrammus Gill, 1858 are among the genera of Characiformes that are not monophyletic (Mirande 2010, Oliveira et al. 2011, Mariguela et al. 2013) and feature a highly problematic taxonomy (Lima et al. 2003). Moenkhausia comprises 81 valid species of small fish widely distributed in the hydrographic basins of South America and Hemigrammus comprises 64 valid species with a wide geographic distribution (Eschmeyer and Fong 2017). There are 35 Hemigrammus species in Brazil, of which 17 are endemic (Lima et al. 2003, Bertaco and Carvalho 2005). Moenkhausia and Hemigrammus share features such as five teeth in the inner series of the premaxilla, and small scales covering the base of the caudal fin. The limits suggested by Eigenmann (1907) for distinguishing these two genera consider the lateral line, completely pored in Moenkhausia and incomplete in Hemigrammus.

Specimens attributed to Hemigrammus marginatus Ellis, 1911 have been captured in the Paraná River basin (Britto et al. 2003, Lima et al. 2003, Graça and Pavanelli 2007); however, there are several taxonomic problems regarding its genus status (de Brito Portela-Castro and Júlio Júnior 2002, Maniglia et al. 2012). Cytogenetic divergences were registered between populations of $H$. marginatus from the upper Paraná River floodplain and individuals from the São Francisco River basin, suggesting that they may be distinct species (de Brito Portela-Castro and Júlio Júnior 2002, Maniglia et al. 2012). Maniglia et al. (2012) evidenced by molecular data the existence of two species of Hemigrammus in the upper Paraná River basin, and that both species were not $H$. marginatus. Maniglia et al. (2012) also suggested that further studies using molecular tools should be undertaken to determine the distribution of the Hemigrammus species in the upper Paraná River basin. Ota et al. (2015) have restricted $H$. marginatus to rivers in northeastern Brazil, but that name was used for several years to identify specimens with incomplete lateral line in the upper Paraná River basin. Due to this statement we are herein treating specimens with complete lateral line as Hemigrammus sp.

Moenkhausia bonita Benine, Castro \& Sabino, 2004 has been described from the Baía Bonita, Paraguay River basin, in Bonito, Mato Grosso do Sul State, Southwestern Brazil. Benine et al. (2004) stated that Moenkhausia bonita is similar to Hemigrammus marginatus (herein Hemigrammus sp.), but can be distinguished from the latter by having complete lateral line and a lozenge-shaped spot on the caudal peduncle.

Although the geographical distribution of $M$. bonita has been restricted to the Mato Grosso do Sul State (Froese and Pauly 2017), specimens with its diagnostic features have been captured in the floodplain of the upper Paraná River. However, these specimens exhibit different developmental levels of the lateral line that include complete, discontinuous, and incomplete lateral lines, which is a diagnostic feature of Hemigrammus sp. However, as the specimens have the other diagnostic feature, a lozenge-shaped spot on the caudal peduncle, even the specimens with a lateral line not completely pored have been tentatively identified as M. bonita. The upper Paraná River is an area with specific complex history and evident endemism, at least for the fish groups, because of the migratory barrier formed until recently by the Sete Quedas Falls, which isolated a great part of the icthyofauna of the Upper Paraná River Basin and the ichthyofaunas of the middle and lower stretches of the ParanáParaguay river basin (Britski and Langeani 1988, Langeani et al. 2007), but many species of fish are naturally shared between these basins (Froelich et al. 2017).

Once the correct taxonomic identification is an essential factor for the quantification of species richness, biodiversity patterns, composition, and structuring of communities (Gotelli 2004), the 
employment of molecular techniques is required. Nuclear and mitochondrial markers are highly promising because they reveal the complex evolutionary process of Neotropical fish (Mariguela et al. 2013), taxonomic distinction of the species (Benine et al. 2009) and evaluation of the genetic variability of fish (Oliveira et al. 2002, Prioli et al. 2002, Panarari-Antunes et al. 2012).

Current assays employ molecular tools to analyze the genetic similarities between populations from the type-locality of $M$. bonita and those with several developmental levels of the lateral line, which inhabit the upper Paraná River floodplain, in order to achieve conclusive identification of specimens attributed to M. bonita and Hemigrammus sp. Further, current analysis comprises molecular sequences of other species of the genus Moenkhausia for species delimitation tests.

\section{MATERIALS AND METHODS}

BIOLOGICAL MATERIAL

Specimens previously identified as $M$. bonita $(\mathrm{n}=33)$, M. gracilima Eigenmann, $1908(\mathrm{n}=3)$ and M. intermedia Eigenmann, $1908 \quad(n=3)$ were collected in the upper Paraná River basin. Specimens of $M$. bonita $(\mathrm{n}=7)$ were collected in the Baía Bonita, Paraguay River basin in Bonito, Mato Grosso do Sul State, the type-locality of the species. The specimens were killed by overdosing of clove oil, according to Griffiths (2000). Specimens were collected under a scientific collecting permit (Sisbio 52596-1, process $n^{\circ} 61 / 405817 / 2015$ ), were placed in flasks with ethyl alcohol and stored at $-20^{\circ} \mathrm{C}$. Sample sites are shown in Figure 1.

Total DNA was extracted from muscle tissue samples using the Wizard Genomic DNA Purification Kit (Promega Corporation, USA), according to the manufacturer's instructions. Partial sequences of the mitochondrial gene encoding cytochrome $\mathrm{C}$ oxidase $\mathrm{I}(\mathrm{COI})$ and ribosomal protein $\mathrm{S} 7$ gene intron 1 ( $r p S 7)$ were amplified using polymerase chain reaction (PCR) and primers, as described by Ward et al. (2005) and Chow and Hazama (1998), respectively. PCR mixtures $(25 \mu \mathrm{l})$ containing Tris- $\mathrm{KCl}(20 \mathrm{mM}$ of Tris- $\mathrm{HCl}, \mathrm{pH} 8.4$, and $50 \mathrm{mM}$ of $\mathrm{KCl}$ ), $1.5 \mathrm{mM}$ of $\mathrm{MgCl} 2,2.5 \mathrm{mM}$ of each primer, $0.1 \mathrm{mM}$ of each dNTP, $1 \mu 1$ Taq of DNA polymerase, and $15 \mathrm{ng}$ de mold DNA and water. Temperatures for the amplification were as follows: initial cycle at $94^{\circ} \mathrm{C}, 2 \mathrm{~min} ; 40$ cycles at $94^{\circ} \mathrm{C}, 30 \mathrm{~s} ; 50^{\circ} \mathrm{C}-58^{\circ} \mathrm{C}$ (according to the primer), $40 \mathrm{~s}$; and $72^{\circ} \mathrm{C}, 2 \mathrm{~min}$, followed by a final extension for $5 \mathrm{~min}$ at $72^{\circ} \mathrm{C}$. All extraction and amplification products were quantified by comparison with known quantities of lambda DNA in agarose gel (0.8\%) stained with ethidium bromide. Amplicons were purified according to Rosenthal et al. (1993) and these were subjected to BigDye Terminator Cycle sequencing and DNA sequencing was performed using a MegaBACE DNA Analysis System (Amersham), both according to manufacturer's instructions.

\section{PHYLOGENETIC ANALYSES}

Individual sequences of each gene were edited using BioEdit (Hall 1999) and were later aligned to MEGA 6 (Tamura et al. 2013) using the algorithm Clustal W (Thompson et al. 1994). Exclusion of identical sequences and identification of haplotypes were performed using ElimDupes (https://hcv. lanl.gov/content/sequence/HCV/ToolsOutline. html). MEGA 6 and DNAsp (Librado and Rozas 2009) were employed to characterize the COI locus. The best nucleotide substitution model was generated using jModelTest 2 (Darriba et al. 2012) based on the Bayesian Information Criterion. Partial sequences (522 bp) of the mitochondrial gene $C O I$ were obtained from 46 specimens: $M$. bonita with complete $(\mathrm{n}=16)$, incomplete ( $\mathrm{n}$ $=7)$, or discontinuous $(\mathrm{n}=10)$ lateral lines; and $M$. gracilima $(\mathrm{n}=3)$ and $M$. intermedia $(\mathrm{n}=3)$ 


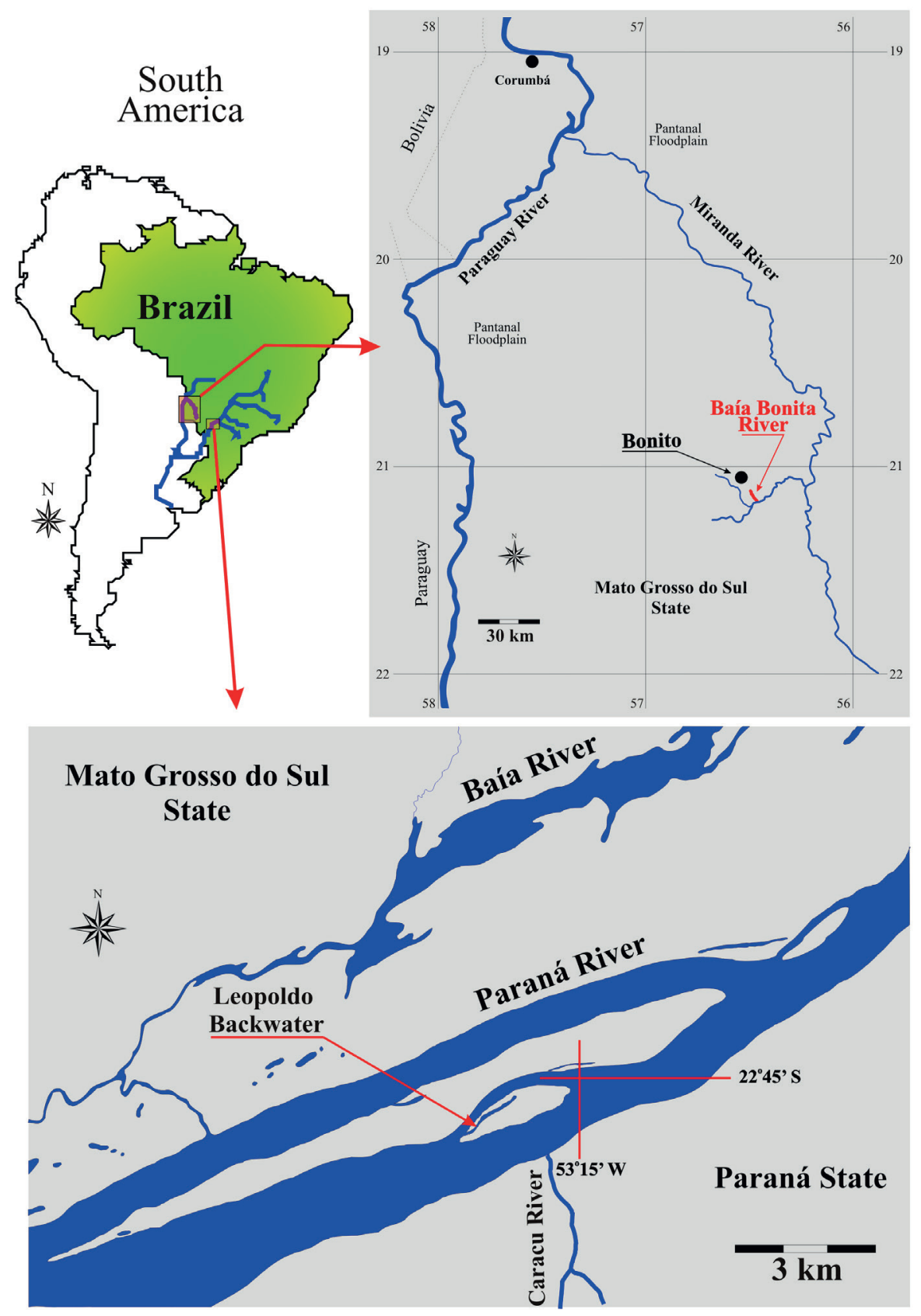

Figure 1 - Sample sites of Moenkhausia: upper Paraná River floodplain; Baía Bonita, affluent of the Miranda River, Paraguay River basin, Brazil.

collected in the upper Paraná River floodplain and; $M$. bonita with complete lateral line $(\mathrm{n}=7)$ from its type-locality. We determined the partial sequences of $r p S 7$ (420 bp) of 19 specimens: $M$. bonita with complete $(\mathrm{n}=8)$, incomplete $(\mathrm{n}=4)$, or discontinuous $(\mathrm{n}=5)$ lateral lines from upper Paraná River floodplain and M. gracilima $(\mathrm{n}=2)$ used as outgroup. Developmental levels of the lateral line of specimens of $M$. bonita are presented in Table SI and Table SII (Supplementary Material). Sequences of Hemigrammus available from BOLD were added inserted to the analyses. $H$. marginatus $(\mathrm{n}=4)$ collected in São Francisco River basin and H. marginatus $(\mathrm{n}=6)$ collected in the upper Paraná 
River basin, wherefore, we are herein treating as Hemigrammus sp. Information on all sequences analyzed and their respective haplotypes are presented in Table SI and Table SII.

An ultrametric tree was constructed using sequences of the COI and a Bayesian inference statistic method using BEAST software (Drummond et al. 2012), accounting for birth-death speciation model and relaxed molecular clock. Analyses were separately replicated at least twice, and the results were analyzed using Tracer 1.6 with an effective sample size of $>200$.

Three phylogenetic trees were constructed using the maximum likelihood method RaxmLGUI (Silvestro and Michalak 2012) using sequences of COI and rpS7, with a rapid bootstrap algorithm with 1,000 resamplings, using the GTR $+\mathrm{G}$ model. A median-joining type haplotype network (Forster and Ro 1994) was generated using PopArt (http:// popart.otago.ac.nz) from the COI sequences of samples from the floodplain of the upper Paraná River. The trees were subsequently edited using FigTree.

\section{LIMITATION OF OPERATIONAL TAXONOMIC UNITS (OTUs)}

Two tests suggested by Zhang et al. (2013) were employed to determine the molecular delimitation of operational taxonomic units (OTUs) as follows: general mixed Yule Coalescent (GMYC) (Fujisawa and Barraclough 2013) and Poisson tree processes (PTP) (Zhang et al. 2013). To increase the robustness of the delimitation tests, 61 sequences of the COI gene of the genus Moenkhausia, which are available from BOLD, were added to the analysis (S1): M. costae (Steindachner, 1907) $(n=1), M$. forestii Benine, Mariguela \& Oliveira, $2009(n=22)$, M. intermedia Eigenmann, 1908 ( $n$ =10), M. oligolepis (Günther, 1864) $(n=14)$, and M. sanctaefilomenae (Steindachner 1907) $(n=14)$.

The GMYC test employs the ultrametric test and delimitation is achieved by comparing the distances of the samples from the most recent common ancestor and speciation event, taking into account a time scale (Fujisawa and Barraclough 2013). An ultrametric tree was built using BEAST to analyze GMYC. The HKY + G model was selected using jModelTest 2 and employed two partitions of the codon bases (first + second position; third position). The GMYC test was conducted in $\mathrm{R}$ using a splits package (Ezard et al. 2015), with a single threshold.

The PTP test employs a phylogenetic tree and considers the number of substitutions according to the length of branches, where the probability of substitutions that lead to speciation follows the Poisson distribution (Zhang et al. 2013). A phylogenetic tree of maximum likelihood, which was used for the PTP test, was constructed from the GTR + G model, taking into account the subpartitions of codon positions (first + second; third position). The test was performed using the bPTP Webserver (http://species.h-its.org/ptp).

\section{RESULTS}

\section{Moenkhausia bonita}

In M. bonita, ten haplotypes were identified within the COI gene of samples from the upper Paraná River floodplain and three haplotypes of samples from the type-locality. Specimens from the typelocality and the upper Paraná River floodplain do not share haplotypes. Sequences of each haplotype are identified in Table SI.

Using the Kimura-2-parameter with 1,000 bootstrap resamplings, the genetic distance of $\mathrm{COI}$ sequences among the $M$. bonita samples from the type-locality and from the upper Paraná River floodplain was $1.25 \%$. Intraspecies variations of the two groups were $0.05 \%$ for the samples from the Paraná River floodplain and $0.03 \%$ for samples of the type-locality. Genetic distances among all haplotypes of Moenkhausia are presented in Table SIII. The genetic distance between M. bonita and 
Hemigrammus sp. was $3.23 \%$, between $M$. bonita and $H$. marginatus was $7.2 \%$.

Different mitochondrial haplotypes in the upper Paraná River floodplain were not associated with different developmental levels of the lateral line (complete, discontinuous, and incomplete). For example, the haplotype BI_9 was shared among specimens with three types of lateral lines, which is also shown by a haplotype network of the medianjoining type (Figure 2).

Phylogenetic trees of maximum likelihood demonstrated that the specimens of M. bonita with different developmental levels of the lateral line and $M$. bonita from the type-locality were in the same clade (Figure 3). Only two variable nucleotide positions and three haplotypes were detected in the 17 partial sequences of $r p S 7$ from samples from the upper Paraná River floodplain. BC 13 was the most frequently detected haplotype $(n=14)$. Further, the haplotype represents specimens with all types of lateral lines. Intraspecies variation of $r p S 7$ among the haplotypes from the upper Paraná River

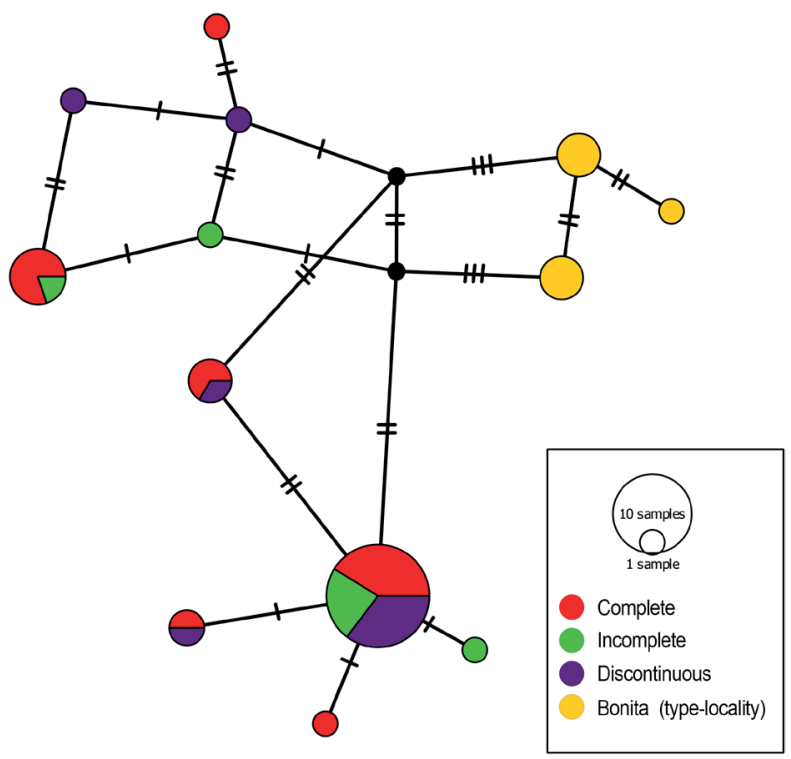

Figure 2 - Median-joining haplotype network from samples of Moenkhausia bonita from the upper Paraná River floodplain with different developmental levels of the lateral line, as well as samples from the Baía Bonita, Mato Grosso do Sul State, with complete lateral lines. floodplain was $0.0032 \%$, and there was a $5.79 \%$ variation between $M$. gracilima and $M$. bonita. A Bayesian tree of $r p S 7$ was generated and shows an introgression of the nuclear haplotype among the different mitochondrial haplotypes independent of the type of lateral line (Figure 3).

\section{DELIMITATION OF OTUs}

Different species of Moenkhausia $(n=107)$ were employed to analyze the delimitation of OTUs (46 and 61 from the present study and BOLD, respectively). The GMYC test employed to identify OTUs, contributed significant results (Table I), considering samples of $M$. bonita collected in the upper Paraná River floodplain and samples collected in the type-locality as a single species, and separating them the other species of Moenkhausia, with a posteriori probability superior 95\%. However, sequences of Moenkhausia acquired from BOLD, which were initially identified as the same species, were grouped into different clusters (Figure 4).

The potentially identical species were indicated by the PTP test with an interval of 10-16 species. The OTUs indicated by the PTP test were the same as indicated by the GMYC test, the specimens of $M$. bonita collected in the upper Paraná River floodplain and samples collected in the typelocality were grouped in the same OTUs. Data that support delimitation are presented in Figure S1 (Supplementary Material).

\section{DISCUSSION}

Our analyses of the COI gene were efficient in discriminating specimens of $M$. bonita, which were sampled in the upper Paraná River floodplain, with different levels of development of the lateral line and specimens of Hemigrammus sp. from the upper Paraná River basin, indicating that they are representatives of different species. The population of $M$. bonita from the upper Paraná River floodplain 


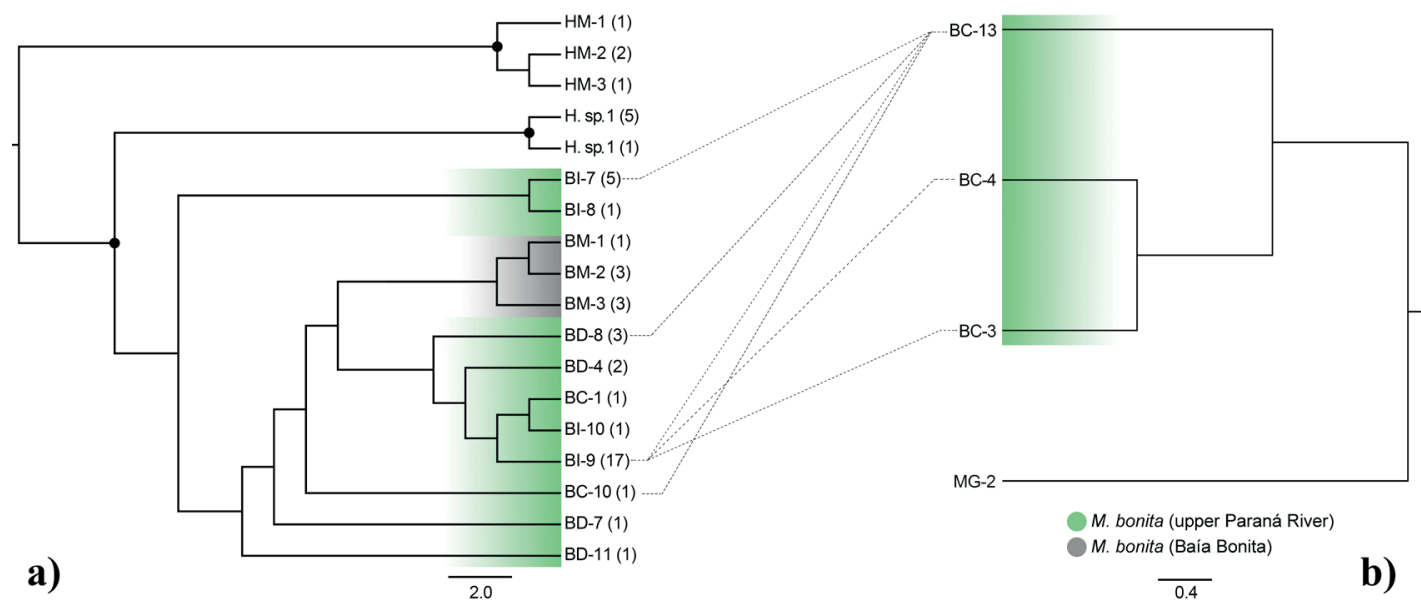

Figure 3 - Mirrored phylogenetic trees of mitochondrial (a) and nuclear (b) haplotypes constructed from specimens of Moenkhausia populations with different developmental levels of the lateral line. Hemigrammus marginatus (HM) and Hemigrammus sp. (H. sp. 1) were used as outgroup. The circles show the bootstrap values $>70$. Numbers between brackets indicate the number of specimens with each haplotype. Dotted lines show the presence of a specific nuclear haplotype of a specific mitochondrial haplotype and vice versa. Sequences of intron 1 of the nuclear gene S7 were not obtained for samples without connection.

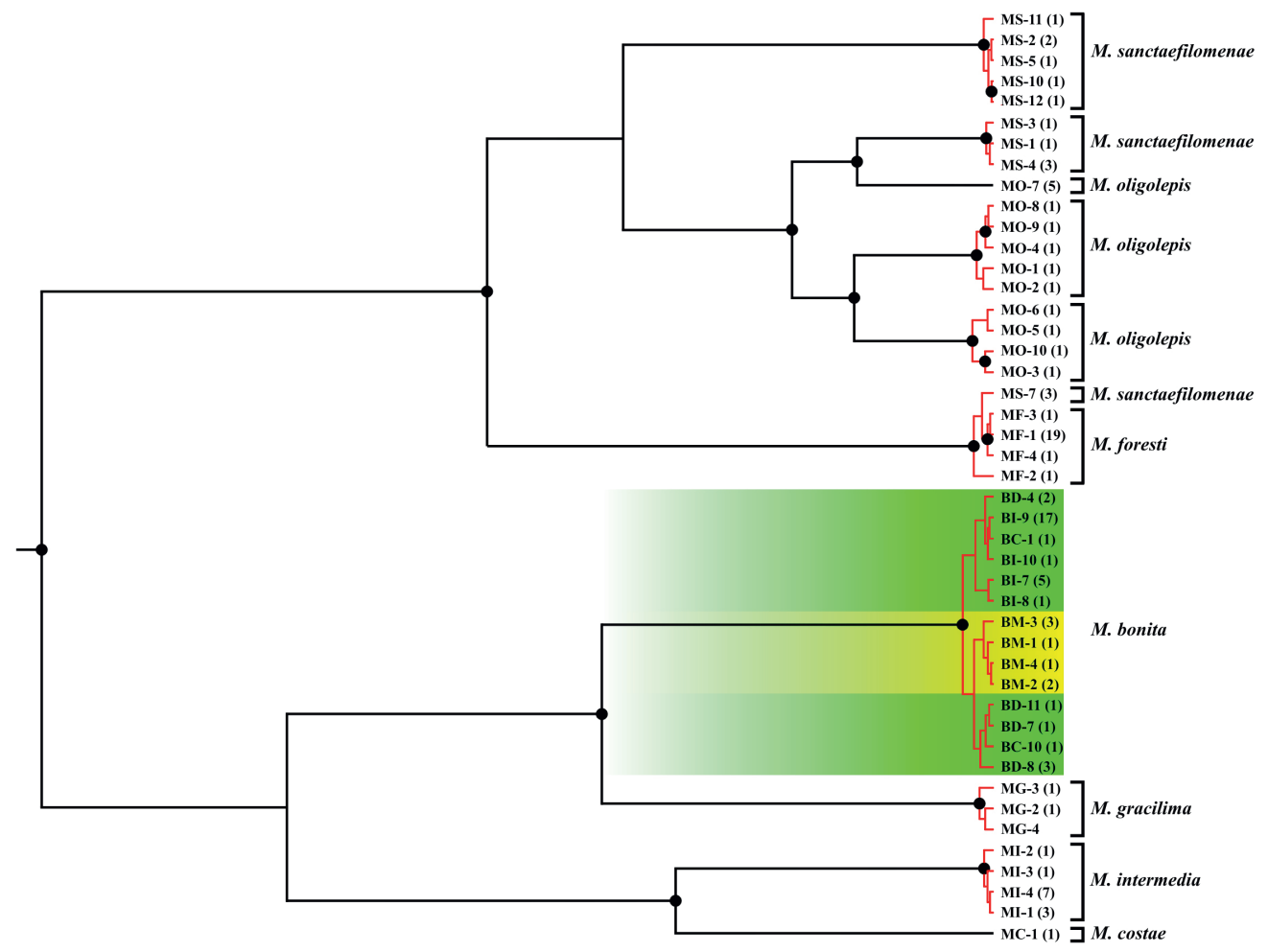

0.02

Figure 4 - Bayesian ultrametric tree of the COI gene and delimitation of OTUs of Moenkhausia, according to the GMYC test (specimens in red represent same cluster inferred by GMYC). Circles represent a posteriori probability $>95 \%$. Only the sequences of the COI of $M$. bonita specimens were obtained in this study, the others were obtained from Genbank (Table SI). Green: Moenkhausia bonita from the upper Paraná river. Grey: Moenkhausia bonita from the type-locality. 
TABLE I

Result the GMYC test for molecular delimitation of OTUs of Moenkhausia.

\begin{tabular}{cc}
\hline Likelihood of null model & $\mathbf{3 1 7 . 7 5 3 1}$ \\
\hline Maximum likelihood of GMYC & \\
model & 332.6118 \\
Likelihood ratio & 29.7174 \\
Result of LR test & $3.523297 \mathrm{e}-07 * * *$ \\
Number of ML clusters & 8 \\
Confidence interval & $8-9$ \\
Number of ML entities & 10 \\
Confidence interval & $10-11$ \\
Threshold time & -0.003537 \\
\hline
\end{tabular}

included 10 haplotypes that were not shared by the population of Hemigrammus sp. with only two haplotype. The Consortium for the Barcode of Life suggests that the rates of interspecies genetic distance should be 10 times greater than those of intraspecies genetic distance, so that species can be considered different (Hebert et al. 2004). The mean rates of interspecies genetic distance determined here were greater than those of intraspecies genetic distance $(0.05 \%$ in $M$. bonita and $3.23 \%$ between M. bonita and Hemigrammuus sp.). Similar results were reported using a DNA barcode to analyze fish (Bellafronte et al. 2013, Pereira et al. 2013).

Although we have found that M. bonita from the upper Paraná River and Hemigrammus sp. represent different species, the percentage of nucleotide differences between them is low and reveals genetic similarity. Specimes of Hemigrammus sp., were long attributed to $H$. marginatus (Ota et al. 2015). In the original description of $M$. bonita morphological similarity with $H$. marginatus is evidenced (Benine et al. 2004). A phylogenetic analysis of the characteristics of the sperm of Moenkhausia and Hemigrammus species among others led Santana et al. (2012) to propose the hypothesis that $M$. bonita and $H$. marginatus represent sister taxa. The same hypothesis was proposed by Mariguela et al. (2013), in a phylogenetic analysis of osteologic characters and external morphology as well as an analysis of molecular data.

Phylogenetic analyses of $C O I$ sequences distinguishing $M$. bonita and Hemigrammus sp., reveals genetic similarities between $M$. bonita from the upper Paraná River and M. bonita specimens from its type-locality. All these specimens are grouped within the same cluster despite their intraspecies nucleotide differences. It is expected that there are high rates of intraspecies divergence among geographically separated populations (Hebert et al. 2003). April and Mayden (2011) found intraspecies variation in freshwater fish that was higher than that in other taxonomic animal groups; this may be explained by low gene flow caused by species fragmentation in water environments (Ward et al. 1994), mainly among small-sized species (April and Mayden 2011). Pereira et al. (2013) found high intraspecies variation among geographically separated small-sized species.

The gene nuclear $r p S 7$ was efficient for assigning specimens from the upper Paraná River floodplain with different developmental levels of the lateral line into the same group that shares the same haplotype, indicating that all specimens with different developmental levels of the lateral line belong to the same species. Further, the phylogenetic tree of $r p S 7$ reveals that there is introgression of the nuclear haplotype among different mitochondrial haplotypes, regardless of the specimen's type of lateral line.

Benine et al. (2009) and Marinho (2010) criticize the validity of the developmental levels of the lateral line as a feature for distinguishing Moenkhausia and Hemigrammus. Characters such as the lateral line that defines Hemigrammus and Moenkhausia may have evolved several times in different strains. Further analysis within the phylogenetic context is required to solve its true importance for delimiting Characidae groups (Marinho 2010). Moenkhausia sanctaefilomenae includes specimens with variations in the 
developmental levels of the lateral line (Benine et al. 2009) similar to that in M. cotinho Eigenmann 1908, and H. barrigonae Eigenmann \& Henn, 1914 (Marinho 2010).

Molecular delimiting tests of OTUs, GMYC, and PTP revealed that specimens collected in the upper Paraná River floodplain with different development levels of the lateral line are M. bonita. The two OTU delimitation tests yielded the same results. The estimated capacity of the tests varies according to the type of data and sampling method (Fujisawa and Barraclough 2013, Zhang et al. 2013).

Molecular delimitation tests of OTUs were useful for distinguishing Moenkhausia species that inhabit different Brazilian hydrographic basins. However, we show here that certain sequences of Moenkhausia acquired from BOLD, which were initially identified as the same species, belong to different species; for example, $M$. sanctaefilomenae was represented in different clusters. In such cases, a taxonomic revision of the groups should be undertaken. According to Benine et al. (2009), M. oligolepis may represents a species complex, and further studies should be undertaken to solve the issue.

In this study, we evidenced that specimens collected in the upper Paraná River floodplain with different development levels of the lateral line belongs to M. bonita. According to the molecular analyses, this trait is not sufficient for distinguishing the species of Moenkhausia and Hemigrammus.

\section{ACKNOWLEDGMENTS}

The authors thank Luíz Fernando Caserta Tencatt for kindly providing specimens from the typelocality. This work was supported by Coordenação de Aperfeiçoamento de Pessoal de Nível Superior (CNPq) and Nupélia.

\section{REFERENCES}

APRIL J AND MAYDEN R. 2011. Genetic calibration of species diversity among North America's freshwater fishes. Proc Natl Acad Sci USA 108: 10602-10607.

BELLAFRONTE E, MARIGUELA TC, PEREIRA LHG, OLIVEIRA C AND MOREIRA-FILHO O. 2013. DNA barcode of Parodontidae species from the La Plata river basin - applying new data to clarify taxonomic problems. Neotrop Ichthyol 11: 497-506.

BENINE RC, CASTRO RMC AND SABINO J. 2004. Moenkhausia bonita: A New Small Characin Fish from the Rio Paraguay Basin, Southwestern Moenkhausia bonita: A New Small Characin Fish from the Rio Paraguay Basin, Southwestern Brazil (Characiformes: Characidae). Copeia, p. 68-73.

BENINE RC, MARIGUELA TC AND OLIVEIRA C. 2009. New species of Moenkhausia Eigenmann, 1903 (Characiformes: Characidae) with comments on the Moenkhausia oligolepis species complex. Neotrop Ichthyol 7: 161-168.

BERTACO VA AND CARVALHO TP. 2005. New characid fish, Hemigrammus skolioplatus (Characiformes: Characidae) from upper rio Tapajós drainage, Central Brazil. Comun Museu Ciências Tecnol PUCRS, Série Zoologia 18: 141-150.

BRITSKI HA AND LANGEANI F. 1988. Pimelodus paranaensis, sp. n., um novo Pimelodidae (Pisces, Siluriformes) do alto Paraná, Brasil. Rev Bras Zool 5: 409417.

BRITTO S, SIROL R AND VIANNA N. 2003. Peixes do rio Paranapanema. São Paulo: Duke Energy Internacional Geração Paranapanema, 112 p.

CHOW S AND HAZAMA K. 1998. Universal PCR primers for $\mathrm{S} 7$ ribosomal protein gene introns in fish. Mol Ecol 7: 1255-1256.

DARRIBA D, TABOADA GL, DOALLO R AND POSADA D. 2012. jModelTest 2: more models, new heuristics and parallel computing. Nat Methods 9: 772-772.

DE BRITO PORTELA-CASTRO AL AND JÚLIO JÚNIOR HF. 2002. Karyotype Relationships among Species of Subfamily Tetragonopterinae (Pisces, Characidae): Cytotaxonomy and Evolution Aspects. Cytologia 67: 329336.

DRUMMOND AJ, SUCHARD MA, XIE D AND RAMBAUT A. 2012. Bayesian Phylogenetics with Beauti and the Beast 1.7. Mol Bio Evol 29: 1969-1973.

EIGENMANN CH. 1907. On Further Collections of Fishes from Paraguay. n. 4: Ann. Carnegie Mus, p. 108-157.

ESCHMEYER WN AND FONG JD. 2017. Species of fishes by family/subfamily. Available at: http://researcharchive. calacademy.org/research/ichthyology/catalog/ SpeciesByFamily.asp. Accessed on 01/06/2017. 
EZARD T, FUJISAWA T AND BARRACLOUGH TG. 2015. SPLITS: Species' Limits by Threshold Statistics. R package version 1.0-18/r45.

FORSTER P AND RO A. 1994. Median-Joining Networks for Inferring Intraspecic Phylogenies. Mol Bio 16: 37-48.

FROELICH O, CAVALLARO M, SABINO J AND VILELA MJA. 2017. Checklist da ictiofauna do estado de Mato Grosso do Sul. Iheringia, Série Zoologia 107: e2017151.

FROESE R AND PAULY D. 2017. FishBase. World Wide Web electronic publication. Available at: www.fishbase. org. Accessed on 10/06/2017.

FUJISAWA T AND BARRACLOUGH TG. 2013. Delimiting species using single-locus data and the generalized mixed yule coalescent approach: A revised method and evaluation on simulated data sets. System Bio 62: 707-724.

GOTELLI NJ. 2004. A taxonomic wish-list for community ecology. Philos Trans R Soc Lond B Biol Sci 359: 585597.

GRAÇA WJD AND PAVANELLI CS. 2007. Peixes da planície de inundação do alto rio Paraná e áreas adjacentes. Maringá: Eduem, p. 241.

GRIFFITHS SP. 2000. The use of clove oil as an anaesthetic and method for sampling intertidal rockpool fishes. J Fish Biol 57: 1453-1464.

HALL TA. 1999. BioEdit: a user-friendly biological sequence alignment editor and analysis program for Windows 95/98/ NT. Nucleic Acids Sym Ser 41: 95-98.

HEBERT PDN, CYWINSKA A, BALL SL AND DEWAARD JR. 2003. Biological identifications through DNA barcodes. Proc R Soc Biol Sci Ser B 270: 313-321.

HEBERT PDN, PENTON EH, BURNS JM, JANZEN DH AND HALLWACHS W. 2004. Ten species in one: DNA barcoding reveals cryptic species in the neotropical skipper butterfly Astraptes fulgerator. Proc Natl Acad Sci USA 101: 14812-14817.

LANGEANI F, CASTRO RMCE, OYAKAWA OT, SHIBATTA OA, PAVANELLI CS AND CASATTI L. 2007. Diversidade da Ictiofauna do Alto Rio Paraná: Composição atual e perspectivas futuras. Biota Neotrop 7: 181-197.

LIBRADO P AND ROZAS J. 2009. DnaSP v5: A software for comprehensive analysis of DNA polymorphism data. Bioinformat 25: 1451-1452.

LIMA F, MALABARBA LR, BUCKUP PA, SILVA JFPD, VARI RP AND HAROLD A. 2003. Genera Incertae Sedis in Characidae. In: Reis RE, Kullander SO and Ferraris Junior CJ (Eds), Check list of the freshwater fishes of South and Central America, Porto Alegre: Edipucrs, p. 106-169.

MANIGLIA TC, PRIOLI AJ, BIGNOTTO TS, BONI TA, PRIOLI SMAP AND PAVANELLI CS. 2012. Nucleotide diversity of Hemigrammus $\mathrm{cf}$. marginatus (Characiformes,
Characidae) in the upper Paraná river floodplain. Acta Sci Bio Sci 34: 303-309.

MARIGUELA TC, BENINE RC, ABE KT, AVELINO GS AND OLIVEIRA C. 2013. Molecular phylogeny of Moenkhausia (Characidae) inferred from mitochondrial and nuclear DNA evidence. J Zoo Syst Evol Res 51: 327332.

MARINHO MMF. 2010. A new species of Moenkhausia Eigenmann (Characiformes: Characidae) from the rio Xingu basin, Brazil. Neotrop Ichthyol 8: 655-659.

MIRANDE JM. 2010. Phylogeny of the family Characidae (Teleostei: Characiformes): from characters to taxonomy. Neotrop Ichthyol 8: 385-568.

OLIVEIRA AV, PRIOLI AJ, PRIOLI S, PAVANELLI CS, JÚLIO JR HF AND PANARARI RS. 2002. Diversity and genetic distance in populations of Steindachnerina in the upper Paraná river floodplain of Brazil. Genetica 115: 259267.

OLIVEIRA C, AVELINO GS, ABE KT, MARIGUELA TC, BENINE RC, ORTÍ G, VARI RP AND CORRÊA E CASTRO RM. 2011. Phylogenetic relationships within the speciose family Characidae (Teleostei: Ostariophysi: Characiformes) based on multilocus analysis and extensive ingroup sampling. BMC Evol Biol 11: 275.

OTA RP, LIMA FCT AND PAVANELLI CS. 2015. A new species of Hemigrammus Gill, 1858 (Characiformes: Characidae) from the central and western Amazon and rio Paraná-Paraguai basins. Zootaxa 3948: 218-230.

PANARARI-ANTUNES RS, PRIOLI AJ, PRIOLI SMAP, GOMES VN, JÚLIO HF, AGOSTINHO CS, SILVA FILHO JP, BONI TA AND PRIOLI LM. 2012. Genetic divergence among invasive and native populations of Plagioscion squamosissimus (Perciformes, Sciaenidae) in Neotropical regions. J Fish Biol 80: 2434-2447.

PEREIRA LHG, HANNER R, FORESTI F AND OLIVEIRA C. 2013. Can DNA barcoding accurately discriminate megadiverse Neotropical freshwater fish fauna? BMC Genet 14: 20.

PRIOLI S, PRIOLI AJ, JULIO HF, PAVANELLI CS, DE OLIVEIRA AV, CARRER H, CARRARO DM AND PRIOLI LM. 2002. Identification of Astyanax altiparanae (Teleostei, characidae) in the Iguaçú River, Brazil, based on mitochondrial DNA and RAPD markers. Genet Mol Biol 25: 421-430.

ROSENTHAL A, COUTELLE O AND CRAXTON M. 1993. Large-scale production of DNA sequencing templates by microtitre format PCR. Nucl Acid Res 21: 173-174.

SANTANA JCO, BAICERE-SILVA CM, GUSMÃOPOMPIANI P, BENINE RC AND QUAGIOGRASSIOTTO I. 2012. An assessment approach for application of spermatic data in phylogenetic analyses: within the genus Moenkhausia Eigenmann, 1903 (Characiformes: Characidae). Acta Zool, p. 335-354. 
SILVESTRO D AND MICHALAK I. 2012. RaxmlGUI: A graphical front-end for RAxML. Org Divers Evol 12: 335337.

TAMURA K, STECHER G, PETERSON D, FILIPSKI A AND KUMAR S. 2013. MEGA6: Molecular Evolutionary Genetics Analysis version 6.0. Mol Biol Evol 30: 27252729.

THOMPSON JD, HIGGINS DG AND GIBSON TJ. 1994. CLUSTAL W: improving the sensitivity of progressive multiple sequence alignment through sequence weighting, position-specific gap penalties and weight matrix choice. Nucl Acid Res 22: 4673-4680.

WARD RD, WOODWARK M AND SKIBINSKI DOF. 1994. A comparison of genetic diversity levels in marine, freshwater, and anadromous fishes. J Fish Biol 44: 213232.

WARD RD, ZEMLAK TS, INNES BH, LAST PR AND HEBERT PDN. 2005. DNA barcoding Australia's fish species. Philos Trans R Soc Lond B Biol Sci 360: 18471857.

ZHANG J, KAPLI P, PAVLIDIS P AND STAMATAKIS A. 2013. A general species delimitation method with applications to phylogenetic placements. Bioinformat 29: 2869-2876.

\section{SUPPLEMENTARY MATERIAL}

Table SI - Phylogenetic tree of the COI gene and delimitation of OTUs of Moenkhausia, according to the PTP test (specimens in red represent same cluster inferred by PTP).

Table SII - Genetic distances of the COI gene among all Moenkhausia haplotypes.

Table SIII - Genetic distances of the COI gene among all Moenkhausia haplotypes.

Figure S1 - Phylogenetic tree of the COI gene and delimitation of OTUs of Moenkhausia, according to the PTP test (specimens in red represent same cluster inferred by PTP). 